\title{
Influence of the photosynthetic productivity and seed productivity of white lupine plants
}

\author{
V. A. Mazur ${ }^{1}$, R.0. Myalkovsky², K. V. Mazur ${ }^{1}$, H. V. Pantsyreva ${ }^{1 *}$, 0.0. Alekseev ${ }^{1}$ \\ ${ }^{1}$ Vinnytsia National Agrarian University, 3, Soniachna Str., Vinnytsia, Ukraine, 21008 \\ ${ }^{2}$ State Agrarian and Engineering University, 13, Shevchenko Str., Kamianets-Podilskyi, Ukraine, 32300
}

E-mail: pantsyreva@vsau.vin.ua

Received: 05.12.2019. Accepted: 31.12.2019

\begin{abstract}
It studied the influence of complex application of inoculation and retardant on the formation of photosynthetic and seed productivity of white lupine (Lupinus albus L.) plants seed varieties. The field research was conducted on the basis of the research farm "Agronomichne" of Vinnytsia National Agrarian University, village Agronomichne, Vinnytsa district, Vinnytsia region, Ukraine. Features of the growth and development of white lupine (Lupinus albus L.) plants are examined. There has been established a positive effect of the combination of inoculation with the bacterial agent and growth stimulator on the productivity of white lupine, which is important for the formation of high and stable yields. The papers presents the results of studies on the effect of pre-sowing seed treatment and foliar nutrion under conditions of the right-bank Forest-Steppe of Ukraine on the photosynthetic apparatus of white lupine plants. It has been established that bacterial agents and growth stimulators increase white lupine seed productivity due to optimization of the studied technological methods of cultivation. The optimal leaf surface area that provided maximum grain yield has been determined. The research has established a positive effect of pre-sowing seed treatment with the bacterial agent Rhizohumin and the growth stimulator Emistym $C$ and foliar nutrition with Emistym $C$ on the contents of chlorophyll $a+b$, observed the maximum yield of the white lupine leaves. The influence of the investigated technological methods on the formation of the photosynthetic and chlorophyll synthesis in the leaves of white lupine has been proved. The preparations studied induce intensive development of the photosynthetic apparatus, yield increase, improvement of the yield structure and they improve grain quality under conditions of right-bank Forest-Steppe of Ukraine. The issue of seed bacterization and application of growth stimulators requires a more detailed study. Theefore, such researches are relevant and significance in terms of both practical and scientific value.
\end{abstract}

Keywords: White lupine; Assimilation apparatus; Chlorophyll; Variety; Productivity; Growth stimulator; Seed bacterization

\section{Introduction}

Photosynthesis is the only process in the biosphere that leads to the absorption of energy of the Sun and ensures the existence of both plants and all heterotrophic organisms, including white lupine (Rogach, 2009; Mazur and Pantsyreva, 2017). From the size of the photosynthetic apparatus and its activity in the ontogeny of all agricultural plants, including white lupine, depends the level of realization of their genetic potential. However, the potential of this culture is not fully realized, so the issue of regulation of the production process remains relevant. In this regard, the formation of a powerful photosynthetic plant apparatus and ensuring the duration of its productive work is an important scientific problem. Thus, the whole complex of agricultural works in technology white lupine cultivation should create optimal conditions for the formation and functioning of the photosynthetic crop system (Muhammad and Muhammad, 2013; Rai et al., 2017).

Plant productivity is most closely correlated with leaf area or photosynthetic potential. It is known that plants are in competition for assimilates, which are used for the growth of vegetative and reproductive organs. It has been investigated that in the case of an assimilate deficiency, processes are predominant in their distribution, associated with increased production assimilation system Climate resources are important for maximizing the biological potential of agricultural crops. The vegetative period in agricultural crops is related to the amount of precipitation and the presence of heat. Among allocated in Ukraine natural agricultural zones include: Woodland, Forest Steppe and Steppe zones. The Forest Steppe zone occupies 34.9\% of the territory of Ukraine (20291,1 thousand hectares). Right Bank Forest Steppe is characterized by moderatelycontinental climate and belongs to the zone of sufficient moisture. The absence of high altitude increases the free movement of air of various origins, which causes a significant variability of weather processes in separate seasons (Mazur and Pantsyreva, 2017, Furseth, 2012; Madzikane Mlungwana et al., 2017). Under the current experimental data in full of developed plants $40-50 \%$ of leaf surface absorbs $90 \%$ of light energy (Kuryata et al., 2017). Photosynthesis in white lupine leaves occurs in light, which is only about $20 \%$ of the total intensity of midday sunlight. (Madzikane Mlungwana et al., 2017; Rai et al., 2017). In most shaded leaves, assimilates are only sufficient for support their livelihoods, and their share in the formation of the crop is quite small (Polyvanyj and Kuryata, 2015; Ren et al., 2017). It is observed that some plants form much more vegetative mass than is necessary for crop formation. To reduce such costs, breeding (for some crops) went by creating varieties of short-stemmed plants (Luo et al., 2016; Ren et al., 2017)

According to research, white lupine form a leaf apparatus in quite wide range - from 20 to 70 thousand $\mathrm{m}-2$ ha (Mohammad and Mohammad, 2013; Rai et al., 2017 Ren et al., 2017). Plants of most white lupine varieties can develop leaf area within 2500-3000 $\mathrm{cm}-2$. Optimal in this case is considered a leaf apparatus in the range of 40-50 thousand m-2 ha. Excessive leaf surface will not contribute to high crop yields as some of the leaves will be shaded by the upper tiers of the crop. In addition, this shaded part of 
the leaves not only does not give productive returns, but is essentially superfluous, since many nutrients are used to form them (Gonzatto et al., 2016; Khalid et al., 2016; Alexopoulos et al., 2017; Pantsyreva, 2017; Rai et al., 2017; Polyvanyj and Kuryata, 2015). The amount of available nitrogen in the soil is one of the factors limiting crop yields. In the soils of many regions of Ukraine, nitrogenous compounds that are available to the plant are not enough. Accumulate during legumes symbiosis with nodule bacteria biological nitrogen is one of the ways to replenish its reserves. A means of increasing the level of biological fixation of air nitrogen is the inoculation of seeds by highly effective strains of tuber bacteria (Davis, Tim, 2017; Rai et al., 2017; Bollman \&, Vessey, 2006, Merkushyna, AS, 2013; Xing et al., 2016).

In the research papers, there is enough information available on the use of natural growth stimulators and bacterial agents aimed to activate the production process through morphometric changes in the legumes (Xing et al., 2016; Pantsyreva, 2016), cereals (Muhammad and Muhammad, 2013; Luo et al., 2017; Zhao et al., 2017), oilseeds (Khodanitska and Kuryata, 2011; Fu et al., 2014; Froschle et al., 2017), vegetables (Palamarchuk II, 2017, Tubiis et al., 2016; Alexopoulos et al., 2017), industrial crops (Khhodanitska and Kuryata, 2011; Mohammad and Mohammad, 2013; Rai et al., 2017), fruit crops (Ahmed et al., 2012; CruCastilloa et al., 2014), medicinal and decorative crops (Gouveia et al., 2012; Aremu et al., 2017; Madzikane-Mlungwana et al., 2017). Bacterial agents and growth stimulators also increase crop resistance to adverse environmental and biotic factors due to the changes in hormonal status and the activation of antioxidant plant sustems (Javid et al., 2011; Muhammad and Muhammad, 2013; Piotrowska Niczyporuk et al., 2014; Tubi's et al., 2016; Xing et al., 2016; Pantsyreva, 2017).

The researches aimed at establishing the features of the photosynthetic apparatus, peculiarities of formation of the formation of photosynthetic during plant growth and development are of primary importance for assessing the influence of the technological methods on the productivity and quality of the plant grain. Therefore, such researches are of great importance for modern agricultural production (Rogach, 2009; Mazur and Pantsyreva, 2017). Thus, the purpose of this research is to establish the specifics of the assimilation apparatus formation by white lupine crops depending on the technological methods under conditions of the rightbank Forest-Steppe.

\section{Materials and Methods}

The field research (for 2013-2018 years) was conducted on the experimental field "Agronomichne" of Vinnytsia National Agrarian University that was sown with white lupine, village Agronomichne, Vinnitsa district, Vinnytsia region. White lupine variety Veresnevyi was selected as the material for the study.

In the experiment, the effect and interaction of three factors were studied: A-variety, B-pre-sowing seed treatment, C-foliar fertilization. On the day of sowing, white lupine seeds were treated with bacterial Risogumin (600 g per hectare seed) and growth promoter Emistim C (10 ml per $1 \mathrm{t}$ seed) using PKC-20 Super. Growth stimulator Emistim C with a rate of use of $15 \mathrm{ml}$ ha-1 was used in the non-root nutrition. The first foliar nutrition of Emistim $\mathrm{C}$ was carried out in the budding phase, and the second in the phase of seeding. For control, an option is adopted without pre-planting and without extra-root crops. On the day of sowing, white lupine seeds were treated with water in a control.

Risogumin is used to bacterialize lupine seeds in order to improve nitrogen nutrition of plants, increase productivity of culture. Stimulator of growth of plants Emistim C a wide spectrum of action-a product of biotechnological cultivation of mushroom-epiphytes from the root system of medicinal plants. Transparent, colorless, water-alcohol solution. Contains a balanced set of phytohormones of auxin, cytokinin nature, amino acids, carbohydrates, fatty acids, trace elements. Leaf area, photosynthetic potential and net photosynthetic productivity were determined by A.A. Nichiporovich's method.

Statistical analysis of the experimental data was carried out using the computer program STATICA -6. Validity of the difference of the experimental data regarding the control was determined using Student's t-criterion. The tables and figures show the average data over the years of research.

The revealed dependencies (Fig. 4) between the formation of indicators of individual productivity and grain yield of white lupine varieties can be expressed by the following regression equations:

$\mathrm{y}=7.881678+0.066816 \times 1+0.196308 \times 2-0.026010 \times 3$

where $\mathrm{Y}$-grain yield, $\mathrm{t} \mathrm{ha}^{-1}$; $\mathrm{x} 1$-number of beans per plant, pcs plant; $\mathrm{x} 2$-number of grains per plant, pcs; $\mathrm{x} 3-\mathrm{mass}$ of 1.000 seeds, g. In this case, the coefficients of the multiple linear correlation in white lupine were $R=0.904254$ and $R=0.896057$, respectively. The pair correlation coefficients $(r)$ between the grain yield and the number of beans, the number of seeds per plant, and the mass of 1.000 seeds were $0.145801,0.045127,0.09706$. These indicators show a close relationship between the basic indicators of individual plant productivity and the level of grain yield of white lupine.

\section{Results and Discussion}

The formation of leaf area in different phases of growth and development of white lupine was influenced by the pre-sowing treatment of seeds by tuber bacteria and growth promoter in combination with foliar nutrition. (Mazur, 2018; Rogach, 2009; Mazur and Pantsyreva, 2017). Thus, in the phases of branching and budding the influence of the studied technological techniques on the indices of the leaf surface area was insignificant. In areas Veresnevyi variety during budding leaf area index based on pre-seed treatment and foliar fertilizing was within 14.2-15.7 thousand $\mathrm{m}^{-2} \mathrm{ha}$, and during the period of full bloom - from 22.3 to 27.6 thousand $\mathrm{m}^{-2}$ ha (Table 1 ).

Found that the highest rate of leaf surface area hectare white lupine Veresnevyi variety -43.7 thousand $\mathrm{m}^{-2}$ ha was formed in the early stage of grain filling a variant using bacterial drug Ryzohumin combined with growth promoters Emistim $\mathrm{C}$ with two foliar feeding Emistim C. This indicator was higher than the control by 8.1 thousand $\mathrm{m}^{-2}$ ha.

During the years of research, the relationship between the process of leaf lupine surface formation and elements of cultivation technology was observed. The results of the conducted researches showed that the choice of varieties with little damage to pests and diseases, phases of vegetation and technological methods (Figure 1) was of great importance for the functioning of the leaf surface. 
Table 1. Formation of leaf area in white lupine depending on pre-sowing seed treatment and foliar nutrition (average of 20132015).

\begin{tabular}{|c|c|c|c|c|c|c|}
\hline \multicolumn{3}{|l|}{ Factors } & \multicolumn{4}{|c|}{ Periods of vegetation of plants } \\
\hline $\begin{array}{l}\text { Pre-sowing } \\
\text { treatment }\end{array}$ & seed & $\begin{array}{l}\text { Foliar nutrition with } \\
\text { Emistym C }\end{array}$ & $\begin{array}{l}\text { Full } \\
\text { germination } \\
\text { - budding }\end{array}$ & $\begin{array}{l}\text { Full } \\
\text { germination - } \\
\text { full bloom }\end{array}$ & $\begin{array}{l}\text { Full } \\
\text { germination }\end{array}$ & $\begin{array}{l}\text { Full germination } \\
-\quad \text { physiological } \\
\text { maturity }\end{array}$ \\
\hline & & & & & $\begin{array}{l}\text { Beginning } \\
\text { of seeding }\end{array}$ & \\
\hline \multirow{3}{*}{$\begin{array}{l}\text { Without } \\
\text { sowing } \\
\text { treatment }\end{array}$} & \multirow{3}{*}{$\begin{array}{l}\text { pre- } \\
\text { seed }\end{array}$} & Without Nutrition & 14.2 & 22.3 & 35.6 & 28.3 \\
\hline & & Single Nutrition & 14.3 & 23.1 & 36.1 & 29.9 \\
\hline & & Double Nutrition & 14.3 & 23.1 & 36.2 & 30.2 \\
\hline \multirow{3}{*}{\multicolumn{2}{|c|}{ Rhizohumin }} & Without Nutrition & 14.7 & 23.9 & 37.1 & 30.9 \\
\hline & & Single Nutrition & 14.8 & 25.2 & 39.5 & 31.6 \\
\hline & & Double Nutrition & 14.8 & 25.2 & 39.6 & 32.7 \\
\hline \multirow{3}{*}{\multicolumn{2}{|c|}{ Emistym C }} & Without Nutrition & 15.0 & 25.4 & 40.1 & 32.9 \\
\hline & & Single Nutrition & 15.1 & 26.3 & 42.4 & 33.5 \\
\hline & & Double Nutrition & 15.1 & 26.3 & 42.5 & 34.1 \\
\hline \multirow{3}{*}{$\begin{array}{l}\text { Rhizohumin } \\
\text { Emistym C }\end{array}$} & \multirow[t]{3}{*}{+} & Without Nutrition & 15.5 & 26.4 & 42.7 & 34.3 \\
\hline & & Single Nutrition & 15.7 & 27.6 & 43.6 & 36.1 \\
\hline & & Double Nutrition & 15.7 & 27.6 & 43.7 & 37.5 \\
\hline
\end{tabular}

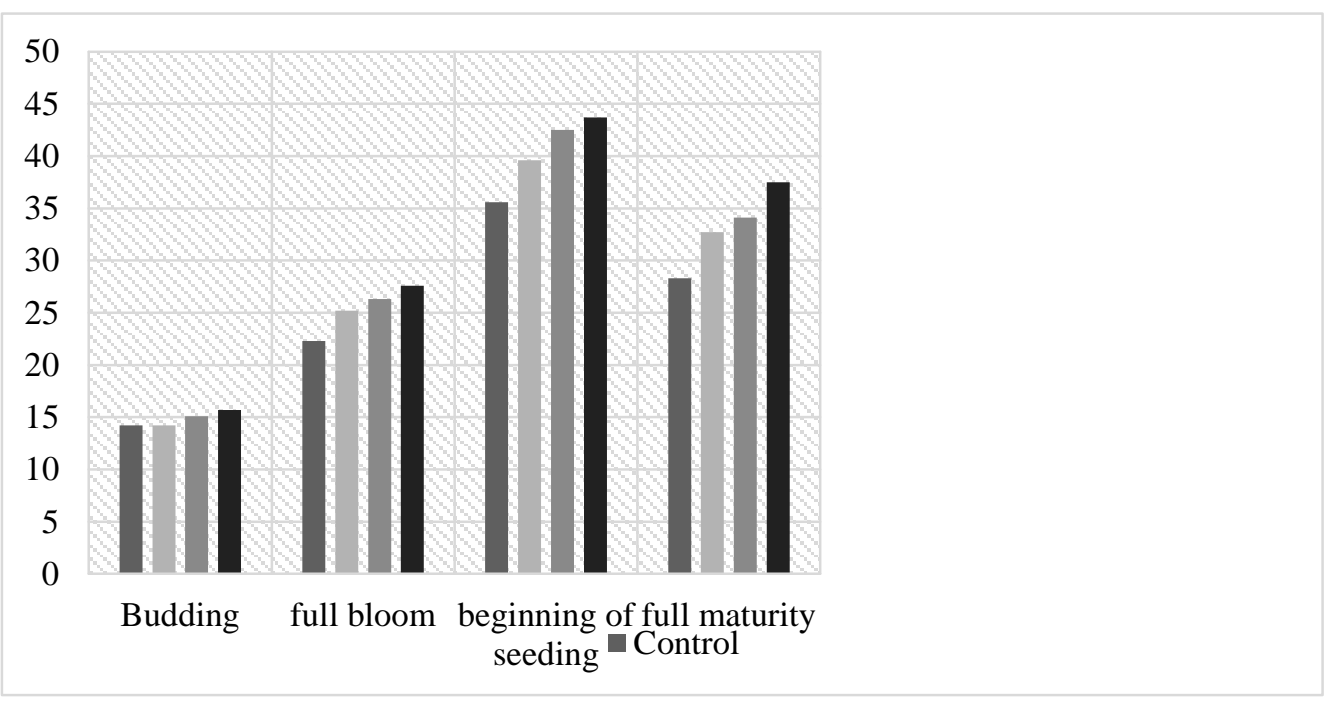

Figure 1. Dynamics of the leaf surface area of white lupine plants of Veresnevyi variety depending on technological methods, thousand $\mathrm{m}^{2}$ per ha (2013-2015)

It was established that the highest index of the area of the leaf surface per hectare of lupine of the white variety of the Veresnevyi 43.7 thousand $\mathrm{m}^{-2}$ ha was formed in the phase of the beginning of the filling of grain in the variant with the use of the bacterial preparation Risogumin in combination with growth stimulator Emistim $\mathrm{C}$ with two extracorporeal feedings Emistim $\mathrm{C}$. This indicator was greater than control at 8.1 thousand $\mathrm{m}^{-2}$ ha. The records taken during the trial have showed that pre-sowing seed treatment of white lupine with the bacterial agent Rhizohumin in combination with the growth stimulator Emistym $\mathrm{C}$ with double foliar nutrition with Emistym $\mathrm{C}$ have a positive effect on the formation of photosynthetic apparatus of plants and on chlorophyll content in the leaves of white lupine (Table 2). It is proved that the effectiveness of application during pre-sowing seed treatment of the bacterial agent Rhizohumin and the growth stimulator Emistym $\mathrm{C}$ and foliar nutrition with the growth stimulator Emistym $\mathrm{C}$ is marked in the phase of physiological maturation. Thus, the highest figures of formation of photosynthetic potential of white lupine plants were observed in the period of full germination - physiological maturity in the variants where pre-sowing seed treatment involved a bacterial agent and a growth stimulator in combination with with double foliar nutrition and amounted to 2.061, which exceeded the control variant by $27.0 \%$. The increase in crop yield depends on both the factors affecting photosynthesis and the complex of physiological processes associated with it (water exchange, nutrition, growth). The formation of a well-developed photosynthetic apparatus that is optimal in volume, dynamics and intensity of functioning is the key to formation of organic matter, biological and commodity yields. Many authors indicate that the biological yield depends on the content of pigments, primarily chlorophylls in the assimilating organs of plants, the time and intensity of their work. The content of chlorophyll in the leaves affects the intensity of photosynthesis, accumulation of dry matter, and, finally, their productivity. The need for research in this area is caused by the fact that the total mass of the green pigment and its concentration in leaf mesophillous and the size of the assimilation surface are considered as a basis for the potential of photosynthetic activity of the plant organic as a whole. 
Table 2. Formation of the photosynthetic potential of white lupine of Veresnevyi variety depending on pre-sowing seed treatment and foliar nutrition, million $\mathrm{m}^{2}$ per ha (average for 2013-2017).

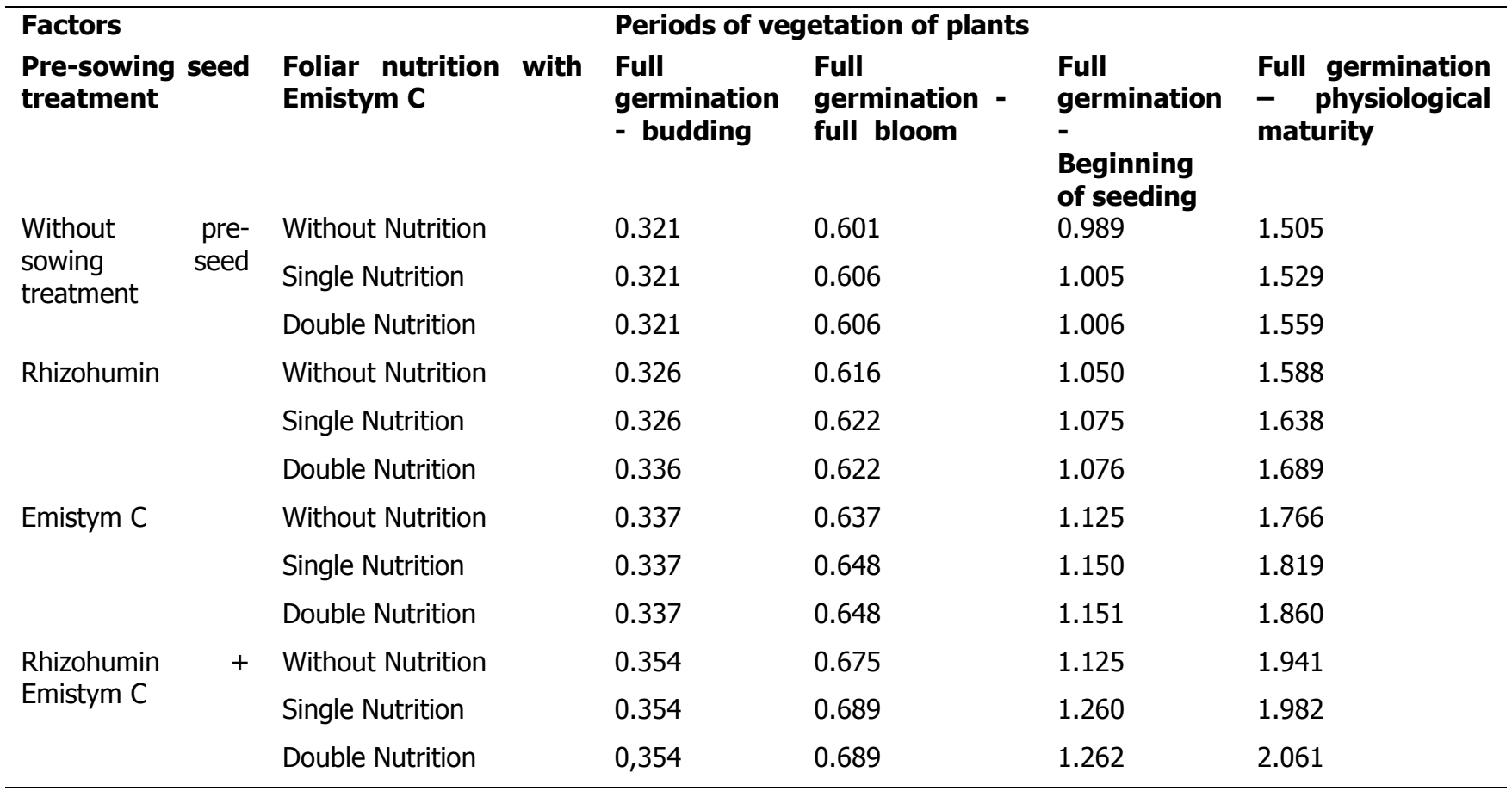

LSD0.5 million $\mathrm{m}^{-2}$ per ha: A-0.05; B-0.6; C-0.07; AB-0.12; AC-0.11; BC-0.14; ABC-0.09

2013 LSD0.5 t ha-1: A-0.04; B-0.05; C-0.04; AB-0.06; AC-0.06; BC-0.07; ABC-0.10

2014 LSD0.5 tha ${ }^{-1}: A-0.05 ; B-0.06 ; C-0.05 ; A B-0.08 ; A C-0.07 ; B C-0.08 ; A B C-0.14$

2015 LSD0.5 t ha ${ }^{-1}$ : A-0.06; B-0.07; C-0.05; AB-0.08; AC-0.07; BC-0.10; ABC-0.13

Availability of the positive effect of pre-sowing seed treatment and foliar nutrition on the chlorophyll content in white lupine leaves was established (Table 3).

Table 3. Chlorophyll content in while lupine depending on pre-sowing seed treatment and foliar nutrition (average of 2013-2017).

\section{Factors}

\section{Pre-sowing treatment}

without pre-sowing seed

treatment

Rhizohumin

Emistym C

Rhizohumin

Emistym C

\section{seed Foliar nutrition with Emistym C}

Without Nutrition

Single Nutrition

Double Nutrition

Without Nutrition

Single Nutrition

Double Nutrition

Without Nutrition

Single Nutrition

Double Nutrition

Without Nutrition

Single Nutrition

Double Nutrition

\section{Chlorophyll content in the leaves, $\mathrm{mg} \mathrm{g}^{-1}$ of crude mass}

\section{Chlorophyll content in the leaves, $\mathrm{mg} \mathrm{m}^{-2}$}

Pre-sowing seed treatment of white lupine plants both with Rhizohumin and Emistym C with subsequent foliar nutrition of plants with Emistym C provided the highest pigment content in the experiment, both in terms of crude mass and per unit of area. Thus, this indicator in the plants of Varesvenyi variety was $2.87 \mathrm{mg} \mathrm{g}^{-1}$ and $4802,12 \mathrm{mg} \mathrm{m}^{-2}$, respectively. The maximum value of the white lupine grain yield of Veresvenyi variety was obtained in the trial variants with pre-sowing seed treatment with the inoculant Rhizohumin and growth stimulator Emistym $C$ in combination with double foliar nutrition with Emistym C (Table 4). At the same time, the grain yield was $3.61 \mathrm{t} \mathrm{ha}^{-1}$, and it exceeded the control variant by $0.65 \mathrm{t} \mathrm{ha}^{-1}$ or $18 \%$, respectively. It has been established that foliar nutrition with Emistym $\mathrm{C}$ provided an increase in the grain yield of white lupine. However, the increase in grain yield depended on the pre-sowing seed treatment, which involved foliar nutrition. Double foliar nutrition on the trial sites without presowing seed treatment resulted in the yield increase of $0.21 \mathrm{t} \mathrm{ha}^{-1}$. 
Table 4. Grain yield of while lupine depending on pre-sowing seed treatment and foliar nutrition, $\mathrm{t}$ ha ${ }^{-1}$ (average of 2013-2015).

\begin{tabular}{|c|c|c|c|c|c|}
\hline \multicolumn{2}{|l|}{ Factors } & \multicolumn{3}{|l|}{ Years } & \multirow{2}{*}{ Average } \\
\hline $\begin{array}{l}\text { Pre-sowing } \\
\text { treatment }\end{array}$ & $\begin{array}{l}\text { Foliar nutrition with } \\
\text { Emistym C }\end{array}$ & 2013 & 2014 & 2015 & \\
\hline pre-sowing & without nutrition & 3.08 & 3.24 & 2.55 & 2.96 \\
\hline \multirow[t]{2}{*}{ seed treatment } & single nutrition & 3.13 & 3.35 & 2.59 & 3.02 \\
\hline & double nutrition & 3.18 & 3.42 & 2.62 & 3.17 \\
\hline \multirow[t]{3}{*}{ Rhizohumin } & without nutrition & 3.15 & 3.71 & 2.90 & 3.25 \\
\hline & single nutrition & 3.31 & 3.88 & 2.94 & 3.38 \\
\hline & double nutrition & 3.40 & 3.90 & 3.05 & 3.45 \\
\hline \multirow[t]{3}{*}{ Emistym C } & without nutrition & 3.10 & 3.68 & 2.82 & 3.20 \\
\hline & single nutrition & 3.20 & 3.74 & 2.86 & 3.27 \\
\hline & double nutrition & 3.31 & 3.81 & 2.93 & 3.35 \\
\hline \multirow{3}{*}{$\begin{array}{l}\text { Rhizohumin + Emistym } \\
\text { C }\end{array}$} & without nutrition & 3.08 & 3.62 & 2.88 & 3.19 \\
\hline & single nutrition & 3.12 & 3.85 & 3.01 & 3.32 \\
\hline & double nutrition & 3.58 & 4.10 & 3.15 & 3.61 \\
\hline
\end{tabular}

LSD0.5 t ha ${ }^{-1}$ : A-0.07; B-0.10; C-0.08; AB-0.14; AC-0.12; BC-0.17; ABC-0.24

2013 LSD0.5 t ha-1: A-0.04; B-0.05; C-0.04; AB-0.07; AC-0.06; BC-008; ABC-0.12

2014 LSD0.5 tha ${ }^{-1}$ : A-0.05; B-0.06; C-0.06; AB-0.09; AC-0.08; BC-0.11; ABC-0.16

2015 LSD0.5 tha ${ }^{-1}$ : A-0.04; B-0.06; C-0.05; AB-0.08; AC-0.07; BC-0.10; ABC-0.14

While the application of double foilar nutrition with the growth stimulator Emistym C combined with pre-sowing seed treatment with the inoculant Rhizohumin and growth stimulator Emistim C provided a maximum grain yield increase of $0.65 \mathrm{t}$ ha ${ }^{-1}$. In the variants where pre-sowing seed treatment was conducted by the bactericidal agent Rhizohumin separately from the growth stimulator Emistym C, the application of double foliar nutrition resulted in somewhat lower yield increase of $0.49 \mathrm{t} \mathrm{ha}^{-1}$ and $0.39 \mathrm{t} \mathrm{ha}^{-1}$ or $14.2 \%$ and $12.0 \%$, respectively. Consequently, there was revealed a significant effect of foliar nutrition with Emistym $\mathrm{C}$ combined with pre-sowing seed treatment with the bacterial agent Rhizohumin and growth stimulator Emistym C.

\section{Conclusion}

Thus, the activation of photosynthetic productivity of white lupine crops is very important for the formation of a high and sustainable yield of its seeds. Application of the bacterial agent Rhizohumin and the growth stimulator in combination with the double foliar nutrition with the growth stimulator Emistym C during pre-sowing treatment of white lupine seeds promoted the increase of the leaf area, formation of photosynthetic apparatus of plants and chlorophyll content in the leaves. The highest stimulatory effect was obtained in the variant of pre-sowing seed treatment with Rhizohumin + Emistym $\mathrm{C}+$ double foliar nutrition with Emistym C.

\section{References}

Ahmed, W., Tahir, F., Rajwana, I., Raza, S., Asad, H.U. (2012). Comparative evaluation of plant growth regulators for preventing premature fruit drop and improving fruit quality parameters in Dusehri Mango. International Journal of Fruit Science, 12, $372-389$.

Alexopoulos, A.A., Karapanos, I.C., Akoumianakis, K.A., Passam, H.C. (2017). Effect of gibberellic acid on the growth rate and physiological age of tubers cultivated from true potato seed. Journal of Plant Growth Regulation, 36(1), 1-10.

Bollman, M., Vessey. (2006). Differential effects of nitrate and ammonium supply on nodule initiation, development, and distribution on roots of pea (Pisum sativum L.). Canadian Journal of Botany. Vol. 84, № 6, 893-903.

Cruz-Castilloa, J.G., Baldicchib, A., Frionib, T., Marocchic, F., Moscatellod, S., Proiettid, S., Battistellid, A., Famianib, F. (2014). Preanthesis CPPU low dosage application increases Hayward kiwifruit weight without affecting the other qualitative and nutritional characteristics. Food Chemistry, 158(1), 224-228.

Davis, T.D. (2017). Soybean photosynthesis and growth as influenced by flurprimidol. Compar. Phisiol. and Ecol. 1986. Vol. 11, № 4, 166-169.

Didur, I.M., Prokopchuk, V.M., Pantsyreva H.V. (2019). Investigation of biomorphological and decorative characteristics of ornamental species of the genus Lupinus L.. Ukrainian Journal of Ecology, 9(3), 287-290.

Froschle, M., Horn, H., Spring, O. (2017). Effects of the cytokinins 6-benzyladenine and forchlorfenuron on fruit-, seed- and yield parameters according to developmental stages of flowers of the biofuel plant Jatropha curcas (Euphorbiaceae). Plant Growth Regulation, 81(2), 293-303.

Fu, Q., Niu, L., Zhang, Q., Pan, B-Z., He, H., Xu, Z-F. (2014). Benzyladenine treatment promotes floral feminization and fruiting in a promising oilseed crop Plukenetia volubilis. Industrial Crops and Products, 59, 295-298.

Furseth, B. (2012). Soybean Response to Soil Rhizobia and Seed-applied Rhizobia Inoculants in Wisconsin. Crop Science. Vol. 52, № $1 ., 339-344$.

Gonzatto, M.P., Boettcher, G.N., Schneider, L.A., Lopes, A.A., Junior, J.C. S., Petry, H. B., Oliveira, R.P., Schwarz, S.F. (2016). 3,5,6trichloro-2-pyridinyloxyacetic acid as effective thinning agent for fruit of Montenegrina mandarin. Ciencia Rural, 46(12), $2078-2083$.

Gouveia, E.J., Rocha, R.B., Galveas, B., Ramalho, L.A. R. Ferreira, M. G. R., Dias, L. A.S. (2012). Grain yield increase of physic nut by fieldapplication of benzyladenine. Pesquisa Agropecuária Brasileira, 47(10), 1541-1545.

Javid, M.G., Sorooshzadeh, A., Sanavy, S. A. M. M., Allahdadi, I., Moradi., F. (2011). Effects of the exogenous application of auxin and cytokinin on carbohydrate accumulation in grains of rice under salt stress. Plant Growth Regulation, 65(2), 305-313.

Khalid, S., Malik, A. U., Khan, A. S., Razzaq, K., Naseer, M. (2016). Plant growth regulators application time influences fruit quality and storage potential of young kinnow mandarin trees. International Journal of Agriculture and Biology, 18, $623-629$. 
Khodanitska, O. O., Kuryata, V. G. (2011). The effect of treptolem on seed yield and quality characteristics of flaxseed oil. Forage and feed production, 70, 54-59.

Kuryata, V. G., Poprotska, I. V., Rogach, T. I. (2017). The impact of growth stimulators and retardants on the utilization of reserve lipids by sunflower seedlings. Regulatory Mechanicms in Biosystems, 8(3), 317-322.

Luo, Y., Yang, D., Yin, Y., Cui, Z., Li, Y., Chen, J., Zheng, M., Wang, Y., Pang, D., Li, Y., Wang, Z. (2017). Effects of exogenous 6-BA and nitrogen fertilizers with varied rates on function and fluorescence characteristics of wheat leaves post anthesis. Scientia Agriculturalura Sinica, 49(6), 1060-1083.

Madzikane-Mlungwana, O., Moyo, M., Aremu, A. O., Plíhalova, L., Doleal, K., Staden, J. V., Finnie, J.F. (2017). Differential responses to isoprenoid, N6-substituted aromatic cytokinins and indole-3-butyric acid in direct plant regeneration of Eriocephalus africanus. Plant Growth Regulation, 82(1), 103-110.

Mazur, V.A., Pantsyreva, H.V. (2017). Influence of technological methods of cultivation on the yield and quality of white lupine grain in the conditions of the right-bank forest-steppe of Ukraine. Agriculture and forestry. Vinnytsia, VSAU, № 7. T 1, 27-36.

Mazur, V.A., Didur, I.M., Pantsyreva, H.V., Telekalo, N.V. (2018). Energy-economic efficiency of growth of grain-crop cultures in the conditions of right-bank Forest-Steppe zone of Ukraine. Ukrainian Journal of Ecology. Volume 8. № 4, 26-33.

Mazur V. A., Didur I. M., Pantsyreva H. V., Telekalo N. V. (2018). Energy-economic efficiency of growth of grain-crop cultures in the conditions of right-bank Forest-Steppe of Ukraine. Ukrainian Journal of Ecology, 8(4): 26-33. (in Ukraine).

Mazur, V.A., Mazur, K.V., Pantsyreva, H.V., Alekseev, O.O. (2018). Ecological and economic evaluation of varietal resources Lupinus albus L. in Ukraine. Ukrainian Journal of Ecology, 8(4), 148-153 (in Ukraine).

Mazur, V.A., Mazur, K.V., Pantsyreva, H.V. (2019). Influence of the technological aspects growing on quality composition of seed white lupine (Lupinus albus L.) in the Forest Steppe of Ukraine. Ukrainian Journal of Ecology, 9(1), 50-55.

Mazur, V.A. (2018). Primary introduction assessment of decorative species of the lupinus generation in Podillya. Scientific Bulletin of UNFU, 28(7), 40-43. https://doi.org/10.15421/40280708 (in Ukraine).

Mazur, V.A., Vdovenko, S.A., Pantsyreva, H.V., Palamarchuk, I.I. (2018). Effectiveness of the application of soil milling in the growing of the squash (Cucurbita pepo var. giraumontia) in the right-benk forest stepp of Ukraine. Ukrainian Journal of Ecology, $8(4), 1-5$.

Merkushyna, A.S. (2013). Physiological and biological bases for increasing the productivity of peas. Biological sciences and problems of plant growing, Uman, 8(4), 99-105.

Mesejo, C., Rosito, S., Reig, C., Martínez-Fuentes, A., Agustí, M. (2012). Synthetic auxin 3,5,6-TPA provokes Citrus clementina (Hort. ex Tan) fruitlet abscission by reducing photosynthate availability. Journal of Plant Growth Regulation, 31(2), $186-194$.

Mohammad, N. K., Mohammad, F. (2013). Effect of GA3, N and P ameliorate growth, seed and fibre yield by enhancing photosynthetic capacity and carbonic anhydrase activity of linseed. Integrative Agriculture, 12(7), 1183-1194.

Muhammad, I., Muhammad, A. (2013). Gibberellic acid mediated induction of salt tolerance in wheat plants: Growth, ionic partitioning, photosynthesis, yield and hormonal homeostasis. Environmental and Experimental Botany, 86, 76-85.

Palamarchuk, I.I. (2017). Influence of the variety and growth stimulator of plants on the dynamics of the growth of the area of the squash apparatus zucchini in the conditions of the forest-steppe of the right-bank. Agriculture and forestry. Vinnytsia. №6. 32-40.

Pantsyreva, H.V. (2017). Formation of grain productivity of white lupine depending on technological methods in the right-bank forest-steppe. Dissertation for obtaining a scientific degree of the candidate of agricultural sciences. Kam'ianets-Podilskyi, $100-101$. Pantsyreva, H.V. (2019). Morphological and ecological-biological evaluation of the decorative species of the genus Lupinus L.. Ukrainian Journal of Ecology, 9(3), 74-77.

Pantsyreva, H.V. (2016). The Influence of the Elements of the Technology of Growing on the Individual Productivity of Lupine Plants in the White Conditions of the Right Bank Forest Steppe. Journal DDAEU, Agriculture ecology. Agronomy science. Dnipro. 2, 16. Piotrowska-Niczyporuk, A., Bajguz, A. (2014). The effect of natural and synthetic auxins on the growth, metabolite content and antioxidant response of green alga Chlorella vulgaris (Trebouxiophyceae). Plant Growth Regulation, 73(1), 57-66.

Polyvanyj, S. V., Kuryata, V. G. (2015). Effects of treptolem on morphogenesis, productivity and qualitative characteristics of poppy oil. Agrobiologija, 117(1), 65-72.

Poprotska, I. V., \& Kuryata, V. G. (2017). Features of gas exchange and use of reserve substances in pumpkin seedlings in conditions of skoto- and photomorphogenesis under the influence of gibberellin and chlormequat-chloride. Regulatory Mechanicms in Biosystems, 8(1), 317-322.

Rai, R. K., Tripathi, N., Gautam, D., Singh, P. (2017). Exogenous application of ethrel and gibberellic acid stimulates physiological growth of late planted sugarcane with short growth period in subtropical India. Journal of Plant Growth Regulation, 36(2), 472-486. Ren, B., Zhang, J., Dong, S., Liu, P., Zhao, B. (2017). Regulations of 6-benzyladenine (6-BA) on leaf ultrastructure and photosynthetic characteristics of waterlogged summer maize. Journal of Plant Growth Regulation, 36(3), $743-754$.

Rogach, T. I. (2009). Particularity of morphogenesis and productivity of sunflower plants under the influence of treptolem. Fiziologija Roslyn: Problemy ta Perspektyvy Rozvytku, 2, 680-686.

Tubic, L., Savic, J., Mitic, N., Milojevic, J., Janosevi, D., Budimir, S., Zdravkovic-Korac, S. (2016). Cytokinins differentially affect regeneration, plant growth and antioxidative enzymes activity in chive (Allium schoenoprasum). Plant Cell, Tissue and Organ Culture January, 124(1), 1-14.

Xing, X., Jiang, H., Zhou, Q., Xing, H., Jiang, H., Wang, S. (2016). Improved drought tolerance by early IAA - and ABA-dependent $\mathrm{H} 2 \mathrm{O} 2$ accumulation induced by a-naphthaleneacetic acid in soybean plants. Plant Growth Regulation, 80(3), 303-314.

Zhao, H., Cao, H., Ming-Zhen, P., Sun, Y., Liu, T. (2017). The role of plant growth regulators in a plant aphid parasitoid tritrophic system. Journal of Plant Growth Regulation, 36(4), 868-876.

\section{Citation:}

Mazur, V. A., Myalkovsky, R.O., Mazur, K. V., Pantsyreva, H. V., Alekseev, O.O. (2019 Influence of the Photosynthetic Productivity and Seed Productivity of White Lupine Plants. Ukrainian Journal of Ecology, 9(4), 665-670.

(cc) Br This work is licensed under a Creative Commons Attribution 4.0. License 